УДК 658.114.12.3

\title{
МОДЕЛЮВАННЯ ОРГАНІЗАЦІЇ УПРАВЛІННЯ ІНТЕГРОВАНИМИ КОРПОРАТИВНИМИ СТРУКТУРАМИ
}

\author{
Морозова Л.В., ст. викладач (НА НГУ)
}

У статті на основі екософських позицій розглянуто особливості організації управління розвитком інтеграчійних структур на підгрунті сполучення методів проектного менеджменту й конщепції управління змінами. Розроблено референтну модель регламентації інтеграційних процесів. Обтрунтовано рекурсивну взаємозалежність інтеграчії й дезінтеграиії в прочесі розвитку підприємств та їх об'єднань. Досліджено, що умовою успіху інтеграційного розвитку виступає управління якісними трансформаціями заснованими на концепџії менеджменту змін.

Ключові слова: інтеграційна корпоративна структура, розвиток, референтна модель, управління взаємодією агентів, концепиія менеджменту змін.

\section{МОДЕЛИРОВАНИЕ ОРГАНИЗАЦИИ УПРАВЛЕНИЯ ИНТЕГРИРОВАННЫМИ КОРПОРАТИВНЫМИ СТРУКТУРАМИ}

\author{
Морозова Л.В., ста. преподаватель (НА НГУ)
}

В статье на основе екософских позиций рассмотрены особенности организации управления развитием интеграционных структур на основе сочетания методов проектного менеджмента и концепции управления изменениями. Разработана референтная модель регламентации интеграџионных процессов. Обоснованно рекурсивной взаимозависимость интеграџии и дезинтеграџии в прочессе развития предприятий и их объединений. Исследовано, что условием успеха интеграционного развитие выступает управление качественными трансформачиями основанными на кониепции менеджмента изменений.

Ключевые слова: интеграчионная корпоративная структура, развитие, референтная модель, управления взаимодействием агентов, кониепџия менеджмента изменений.

\section{THE SIMULATION OF MANAGEMENT INTEGRATED CORPORATE STRUCTURES}

\author{
Morozova L.V., senior lecturer \\ (National Academy of the National Guard of Ukraine)
}

Tough competitive conditions of modern economic environment dictate terms on the expansion of integration relations between enterprises of different level and scale. In traditional logistic processes the delayed reaction of the management on relevant challenges of the external environment and the needs of the target segment. As a result of these processes is pertinent to the establishment of integration structures of the enterprises and manage the development of such structures based on the combination of methods of project management and the concept of change management. 
You should note that most existing developments in management organization do not allow simultaneous consideration of the integrated corporate structures in multiple projections.

$G$ the complexity of the management a distinct process necessitated the development of appropriate reference model (efficient business process). Such a model would represent a collection of logically interrelated processes and functions, each of which is specified by the input and output documents, or information objects, as well as the necessary references. The proposed model reflects different options of the integration dynamics. So, if internal integration control objects will be separate units or a dedicated branch of the company. With an external counterparty, this proposes to establish partnership agreements or to merge into a new structure. In addition, the vary will be the subject of management. It will change from the top management of one of the participants of the integration, a dedicated coordination centre, issued in the form of a separate legal entity. It should be noted that since any form of integration involves limiting the freedom of action of enterprises through voluntary delegation by them of their functions and rights to integrated education, the correct choice of development of integration structures is determined not only by the cumulative, progressive changes in a plant and considers various models of institutional equilibrium and depends on the chosen strategic alternatives counterparties and subcontractors. The development process involves a consistent movement from the simple intention of rapprochement of objects to the point where it is difficult to distinguish between integrated objects, that is, until, until you create a new improved system.

Keywords: integration of corporate structure, the development of the reference model to control the interaction of agents, the concept of change management.

Постановка проблеми та її зв'язки 3 науковими чи практичними завданнями. Жорсткі конкурентні умови сучасного економічного середовища диктують умови стосовно розширення інтеграційних підприємствами масштабу. В умовах традиційних логістичних процесів запізнюється реакція менеджменту підприємства на відповідні виклики зовнішнього середовища та потреби цільового сегменту. Внаслідок цих процесів актуального значення набуває створення інтеграційних структур підприємств і управління розвитком таких структур на підгрунті сполучення методів проектного менеджменту й концепції управління змінами.

Аналіз останніх досліджень i публікацій та виділення невирішених частин загальної проблеми. Дослідженню питань формування інтегрованих об'єднань господарюючих суб'єктів присвячені роботи таких дослідників як Д. Старк [5], О.А. Третьяк [6], В.В. Радаев [4]. Роботи зазначених авторів зміщають аспекти уваги менеджерів на групові об'єднання підприємств сітьового типу, які характеризуються наявністю системи внутрішніх ринків, гетерархичной структурою й гнучким складом учасників. У той же час, хоча особливості функціонування таких об'єднань досить повно розглянуті в роботах $[1,2]$, проблеми розробки й впровадження відповідних систем стратегічного управління залишаються недостатньо проробленими в теоретичному й практичному аспектах.

Отже, метою статті є теоретикометодологічне обгрунтування особливостей процесу управління інтеграційними процесами національних підприємств і формування відповідної референтної моделі його організації.

Виклад основного матеріалу дослідження. Слід звернути увагу, що 
більшість наявних розробок з організації управління не допускає одночасного розгляду інтегрованої корпоративної структури у декількох проекціях. Вирішення такого протиріччя можливо на основі використання холархічних моделей, які найкращому образом підходять для управління субцілісними об'єктами (вкладеними ієрархіями), якими здебільшого виявляються корпоративні структури. Відповідно до такого підходу, підприємство, що входить до складу інтегрованого утворення, одночасно являє собою як суму частин, так i частину системи більше високого рівня. Корпорація ж в цілому виступає субцілісним об'єктом верхнього рівня, що задає цільові настанови для об'єктів нижнього рівня (підприємств, які формують базову структуру) й координують процес їхнього досягнення. Такий підхід й пропонується розглядати як підгрунтя реалізації мети дослідження. Відповідно й формована система управління поширюватиметься в межах одного рівня холархії, а кожний член інтегрованої структури матиме власні цілі, завдання й логіку функціонування. Джерелом розвитку у такому випадку стає коопераційна взаємодія й системний сінергізм, що виникає саме на основі розширення інтеграційних можливостей окремих підприємства.

Отже, розвиток інтеграційних структур визначається не тільки кумулятивними прогресивними змінами одного підприємства, а враховує різні моделі інституціональної рівноваги й залежить від вибраних стратегічних альтернатив контрагентів і субпідрядників. При цьому процес розвитку припускає послідовний рух від простого наміру зближення об'єктів до того моменту, коли важко розрізнити інтегровані об'єкти, тобто доти, поки не буде створена нова вдосконалена система.

Складність організації управління означеним процесом обумовила необхідність розробки відповідної референтної моделі (моделі ефективного ділового процесу). Така модель являтиме собою сукупність логічно взаємозалежних процесів і функцій, для кожної 3 яких вказується виконавець, вхідні й вихідні документи або інформаційні об'єкти, а також необхідні посилання. Запропонована модель відбиває різні варіанти інтеграційної динаміки. Так, у випадку внутрішньої інтеграції об'єктами управління виступатимуть окремі підрозділи або виділені філії підприємства. При зовнішній контрагенти, 3 якими пропонується встановити партнерські угоди або здійснити злиття в нову структуру. Крім того, варіюватися буде й суб'єкт управління. Він змінюватиметься від вищого керівництва одного 3 учасників інтеграції, до спеціально виділеного координаційного центра, оформленого у вигляді окремої юридичної особи. Слід зазначити, що оскільки будь-яка форма інтеграції припускає обмеження свободи дій підприємств через добровільне делегування ними частини своїх функцій й прав інтегрованому утворенню, правильність вибору суб'єкта й методів управління набувають особливого значення.

У якості інструментарію для реалізації наведених положень пропонується використання мереж Петрі [3], основаних на побудові двочасткового орієнтованого мультиграфу $N=(P, T, I, O$, $\left.\mu_{0}\right)$, де $P$ - кінцева непуста множина елементів, називаних позиціями; $T$ кінцева непуста множина елементів, називаних переходами; I:P $\times T \rightarrow\{0,1,2 \ldots\}$ й $O: P \times T \rightarrow\{0,1,2 \ldots\}$ - функції інцидентності; $\mu_{0}: P \rightarrow\{0,1,2 \ldots\}$ - початкова розмітка. Моделювання в мережах Петрі здійснюється на рівні подій, послідовність яких утворює необхідну модель процесу. Така модель, розроблена за допомогою пакету програм Time Petri Net Analizer Toolbox, в поєднанні 3 розкриття логіки переходів представлена на рис. 1. 


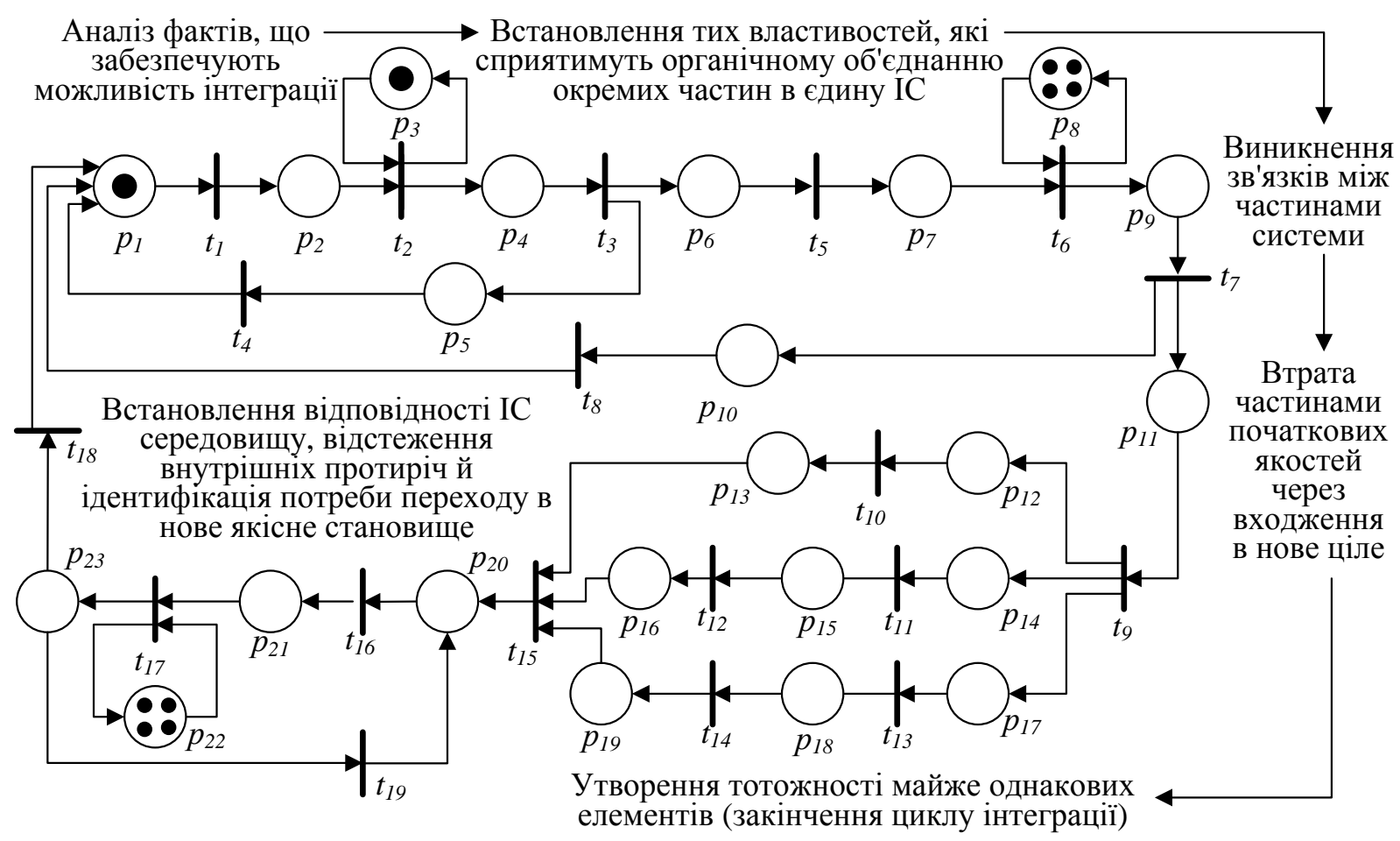

Рис. 1. Референтна модель організації управління інтегращією

Важливою запропонованої моделі є їі орієнтація на методи проектного менеджменту й пульсарний характер інтеграційних процесів. Таке припущення передбачає, що при трансформаціях корпоративні структури часто повторно проходять стани, у яких вони вже раніше були. Результатом реалізації проектів $\epsilon$ правила виконання функцій у формі різних внутрішніх регламентів, які будуть використатися на наступному витку інтеграційного розвитку. Відбиття такого процесу реалізується наступними подіями й спрацюванням переходів: $p_{1}-$ ініціалізація проекту створення або реструктуризації інтеграційної структури, визначень цілей, завдань і принципів інтеграційного розвитку; $t_{1}$ предпроектное обстеження існуючих можливостей та умов інтеграції; $p_{2}$ підготовка концептуальних пропозицій щодо особливостей інтеграційної структури; $t_{2}$ - проведення порівняльної оцінки варіантів й відбір найкращого; $p_{3}-$ перелік потенційних учасників інтеграційної структури (IC); $p_{4}-$ попередньо сформований варіант організації; $t_{3}$ - розробка необхідної установчої документації й проведення техніко-економічного обгрунтування проекту; $t_{4}, p_{5},-$ перехід на новий цикл через неможливість узгодження проекту; $p_{6}$ - підготовка до практичної реалізації проекту.

Крім того, під час реалізації проекту інтеграції необхідно враховувати положення, що діяльність підприємства (що входить у IC) може вважатися ефективної лише в тому випадку, якщо, крім забезпечення власних цілей, вона одночасно сприяє досягненню цілей хоча б деяких інших підприємств. У противному випадку можливе виникнення дезінтеграційних процесів, що призводять до внутрішньо системних конфліктів та можливого розпаду отриманої структури. Саме тому розроблена модель припускає постійний перегляд складу учасників 
інтеграційного процесу, тобто відповідно 3 принципом інтегративізму відбуваються "пульсація" між процесами інтеграції й диференціації (чергування в часі й у просторі динаміки зближення й відторгнення різних об'єктів). Узгодження ж цілей учасників IC моделюється наступним образом: $t_{5}$ обгрунтування необхідності змін й дезінтеграції поточних зв'язків; $p_{7}$ - завдання на доробку проекту; $t_{6}$ - узгодження цілей окремих учасників; $p_{8}-$ масив власних уподобань окремих агентів; $p_{9}-$ узгоджені принципи та правила кооперативної діяльності; $t_{7}$ - оцінка відповідності правил співпраці умовам середовища; $t, p_{10}$ ініціалізація нового циклу через невідповідність та прогнозовані внутрішні конфлікти.

У такий спосіб в інтеграційному розвитку варто розрізняти еволюцію зближення об'єктів доти, поки не буде створена більше складна система. При цьому допускається циклічне повторення періодів диференціації (дезінтеграції) та інтеграції, коли напрямок i форма інтеграції попадає в залежність від чинності дезінтеграційних причин. Такий підхід передбачає нескінченність інтеграційних процесів, оскільки відразу ж після створення нової інтеграційної структури, усередині кожного складового ii об'єкта починається поступове нагромадження якихось руйнівних тенденцій, у наслідку вивідних на новий цикл розвитку.

Більш того, можна наголосити на неможливості єдиного вибору оптимальної інтеграційної структуру й складу елементів, що беруть участь у ній (підприємств) [8]. Саме виникнення внутрішніх протиріч буде виступати основним джерелом розвитку. Таким чином, умовою успіху інтеграційного розвитку виступає управління якісними трансформаціями заснованими на концепції менеджменту змін. В існуючій літературі представлена досить велика кількість підходів до управління трансформаційними процесами, але всі вони грунтуються й тією чи іншою мірою розвивають концепцію К. Левина: "розморожування системи - рух системи заморозожування системи". Саме виконання основного блоку створення цілісності (ініціалізується позицією $p_{11}$ та переходом $t_{9}$ ) приводить до остаточного виникнення нової цілісності й початку дезінтеграційних процесів.

У цьому контексті управління інтеграцією може розглядатися як спосіб упорядкування економічних відносин, відновлення втраченої цілісності. Для його реалізації необхідне проходження ряду етапів. Ці етапи значно розрізнятимуться в залежності від умов конкретної інтеграційної структури. Отже й наступний блок можна вважати варіаційною частиною референтної моделі. Саме тому для iї спрощення виділимо лише напрямки утворення цілісності. Перший напрямок $\left(p_{12} t_{10}, p_{13}\right)-$ інтеграція бачення й корпоративної культури; другий напрямок $\left(p_{14}, t_{11}, p_{15}, t_{12}\right.$, $\left.p_{16}\right)$ - створення єдиної інституціональноінформаційної інфраструктури; третій напрямок $\left(p_{17}, t_{13}, p_{18}, t_{14}, p_{19}\right)-$ створення технологічних взаємозв'язків.

Остання частина моделі являє собою процедуру моніторингу відповідності виробленої структури умовам середовища. Ї̈̈ головним завданням $є$ відстеження моменту початку процедури реконфігурації IC. За для цього виділяють наступні елементи: $t_{15}$ реалізація процедури нормативноправової й інституціональної регламентації результатів циклу інтеграції; $p_{20}$ - закріплення нової організаційної практики; $t_{1}$ - ініціалізація процедури моніторингу відповідності внутрішньої корпоративної організації умовам середовища; $p_{21}$ - перелік параметрів для моніторингу; $t_{1}-$ безпосередня реалізація процедури моніторингу; $p_{22}$ - параметри й показники середовища, необхідні для співставлення; 
$p_{23}$ - результати моніторингу; $t_{18}-$ перехід на новий цикл ре конфігурації через невідповідність; $t_{19}-$ продовження функціонування за заздалегідь узгодженими параметрами.

Висновки. Таким чином, у даному дослідженні представлена референтна модель, яка дозволяє на основі сполучення методів проектного менеджменту й концепції управління змінами підвищити ефективність й забезпечити рекурсивний взаємозв'язок процесів інтеграції й диференціації, що відбуваються в корпоративних структурах.

\section{ПЕРЕЛІК ВИКОРИСТАНИХ ДЖЕРЕЛ}

1. Гарретт Б.Стратегические альянсы: Пер. с англ./ Б. Гарретт, П. Дюсоож . - М.: ИНФРА-М, 2002. - 332 с.

2. Паринов С.И. К теории сетевой экономики/ С.И. Паринов. - Новосибирск: ИЭОППСО РАН, 2002. - 168 с.
3. Питерсон Дж. Теория сетей Петри и моделирование систем: Пер. с англ./ Дж. Питерсон. - М.: Мир, 1984. $264 \mathrm{c}$.

4. Радаев В.В. Социология рынков: к формированию нового направления. М.: ГУ-ВШЭ, 2003. - 324 c.

5. Старк Д. Гетерархия: неоднозначность активов и организация разнообразия / Д. Старк// Экономическая социология. - 2001. - №2. - С. 115 - 132

6. Третьяк O.A/ Сетевые формы межфирменной кооперации / O.A. Третьяк, М.А. Румянцева // Российский журнал менеджмента. - 2003. - №2. - т.1. - С. $25-50$

7. Каличева Н.Є. Логістичні підходи, як основа раціональної організації виробничого процесу на підприємстві/ Н.С. Каличева , В.О. Маслова// Вісник економіки транспорту i промисловості. Збір наук. праць - Харків, УкрДАЗТ, 2014. - № 47. - С. 83 - 86.

\title{
УДК 631.15.3
}

\section{НАПРЯМИ ПОКРАЩЕННЯ МОТИВАЦІї ПЕРСОНАЛУ ПІДПРИЕМСТВА В СУЧАСНИХ УМОВАХ}

\author{
Черкашина М.В. , к.е.н., доцент, \\ Науменко М.О., д.філ. економ. напр., професор (НА НГУ)
}

У статті проаналізовано сучасний стан мотивачії персоналу підприємства харчування. Обтрунтована необхідність конкретизації иляхів підвищення ефективності мотивачії працівників. Виявлені проблеми, які пов'язані з низьким рівнем мотивачї робітників підприємства харчування. Окрему увагу наділено системі бонусів як засобу справедливої диференціації доходів прачівників на підприємстві харчування, мотивації їх до продуктивної регламентованої та творчої праці.

Ключові слова: мотивація, контроль, бонуси, премія, норма виробітки.

(C) Черкашина M.B., Науменко М.O.
Вісник економіки транспорту і промисловості № 58, 2017 